\title{
PERAN HUBUNGAN ORANG TUA DALAM PROSES PEMBELAJARAN ANAK DI MASA COVID 19
}

\author{
Artika Ratu, ${ }^{1 *}$ Sutrisno, $^{2}$ Christiani Hutabarat $^{3}$ \\ Sekolah Tinggi Teologi Moriah Tangerang, Indonesia ${ }^{1,2}$ \\ Sekolah Tinggi Teologi Indonesia Jakarta ${ }^{3}$ \\ Email: artikaratu01@gmail.com*
}

\begin{abstract}
In a family there is a relationship, every family certainly expects a positive relationship in their family, especially between children and parents. But in fact not all families have a positive relationship in their family, there are some families who have a negative relationship in their family, a negative relationship in the family has an impact on children's learning outcomes. The purpose of this study was to determine the impact of a negative relationship between parents and children for learning outcomes. The method used is descriptive qualitative method which is

intended to find, develop and study the truth. The subjects of this study were parents and children. The technique of collecting data in this study is to use a literature review sourced from

books and journals. The results of this study indicate that there is an impact of a negative relationship between parents and children for learning outcomes. In this research, it can also be seen about the real function of the family and the factors that cause the negative relationship.
\end{abstract}

Keywords: relationship, parent-child, learning outcomes

\begin{abstract}
Abstrak
Dalam sebuah keluarga terdapat adanya suatu hubungan, setiap keluarga pastinya mengharapkan hubungan yang positif dalam keluarga mereka terlebih antara anak dan orang tua. Namun pada kenyataanya tidak semua keluarga memiliki memiliki hubungan yang positif didalam keluarga mereka, terdapat beberapa keluarga yang memiliki hubungan negatif dalam keluarga mereka, hubungan yang negatif di dalam keluarga tersebut berdampak pada hasil belajar anak. Tujuan penelitian ini untuk mengetahui dampak hubungan yang negatif antara orangtua dengan anak bagi hasil belajar. Metode yang digunakan adalah metode kualitatif deskriptif yang dimaksudkan untuk menemukan, mengembangkan dan mengkaji kebenaran. Subjek penelitian ini adalah orangtua dan anak. Teknik pengumpulan data pada penelitian ini adalah dengan menggunakan tinjauan pustaka yang bersumber dari buku-buku dan jurnal. Hasil penelitian ini menunjukan

bahwa terdapat dampak dari hubungan yang negatif antara orangtua dengan anak bagi hasil belajar. Dalam penelitian, ini juga dapat dilihat mengenai fungsi dari keluarga yang sesungguhnya dan faktor-faktor penyebab terjadinya hubungan yang negatif tersebut.
\end{abstract}

Kata Kunci: hubungan, orang tua-anak, hasil belajar

\section{PENDAHULUAN}

Pada dasarnya manusia hidup secara bersosial, manusia memerlukan interaksi dengan manusia lain, manusia tersebut juga malakukan aktivitas secara bersama-sama dengan manusia 
lain dalam suatu ruang sosial. ${ }^{1}$ Manusia adalah makhluk sosial, yaitu makhluk yang berhubungan secara timbal-balik dengan manusia lain, tidak dapat hidup sendiri dan memerlukan orang lain dalam kehidupannya. Menurut Kamus Besar Bahasa Indonesia (KBBI) kata hubungan berarti keadaan berhubungan, kontak, sangkut paut, ikatan. ${ }^{2}$ Dengan demikian dapat dipahami bahwa hubungan adalah kesinambungan interaksi antara dua orang atau lebih yang memudahkan proses pengenalan satu akan yang lain. COVID-19 adalah penyakit paling mematikan dan sangat menular yang muncul pada akhir tahun 2019, di Wuhan, Cina yang mempengaruhi jutaan orang di seluruh dunia, menyebabkan Organisasi Kesehatan Dunia (WHO) menyatakan bahwa hal tersebut sebagai pandemi dan keadaan darurat di seluruh dunia. Karena kasus Covid-19 meningkat di seluruh dunia, stres, ketakutan, kecemasan, dan banyak masalah psikologis juga meningkat. ${ }^{3}$ Di rumah sendiri peran anak dalam proses belajar tidak dapat dilaksanakan dengan maksimal jika orang tua kurang memahami tugas dan panggilan ini secara baik. Oleh karena hal tersebut hubungan orang tua dan anak begitu sangat penting.

Hubungan terjadi dalam setiap proses kehidupan manusia. Suatu hubungan dapat ditemukan baik dilingkungan sekolah, masyarakat bahkan di dalam keluarga. Langkah awal sebelum manusia berinteraksi dengan lingkungan sosialnya yang lebih luas adalah berkomunikasi dengan orang yang paling dekat dengannya, yakni keluarga. Pada dasarnya komunikasi merupakan suatu bentuk kegiatan yang dilakukan oleh manusia didalam kehidupannya sehari-hari. Manusia melakukan komunikasi dengan tujuan untuk memberikan dan menerima informasi yang sesuai dengan kebutuhannya. Dalam melakukan komunikasi diharapkan terciptanya suatu hasil yang baik, yaitu komunikasi tersebut berjalan dengan adanya umpan balik dan terdapat informasi yang ingin didapatkan, dan dalam melakukan proses komunikasi, kepuasan menjadi salah satu hasil yang diciptakan dari komunikasi tersebut. ${ }^{4}$

Hubungan di dalam anggota keluarga sangat memiliki pengaruh besar terhadap Pendidikan anak. Keluarga merupakan bagian terkecil dari sebuah sistem yang terdiri atas

\footnotetext{
${ }^{1}$ Dedi Hantono and Diananta Pramitasari, “Aspek Perilaku Manusia Sebagai Makhluk Individu Dan Sosial Pada Ruang Terbuka Publik,” Nature: National Academic Journal of Architecture 5, no. 2 (2018): 85. https://doi.org/10.24252/nature.v5i2a1

${ }^{2} \mathrm{KBBI}$

${ }^{3}$ Divya Dubey, "PSYCHOLOGICAL IMPACT OF COVID-19," COVID-19 Pandemic Update 2020 (Royal Book Publishing, 2020), 165-166. https://doi.org/10.26524/royal.37.15

${ }^{4}$ Reni Agustin and Widayatmoko Widayatmoko, "Pengaruh Komunikasi Interpersonal Dan Iklim Komunikasi Organisasi Terhadap Kepuasan Komunikasi Karyawan Sekretariat Jenderal Kementerian Komunikasi Dan Informatika," Koneksi 3, no. 1 (2019): 163. https://doi.org/10.24912/kn.v3i1.6198
} 
beberapa orang dan nilai-nilai yang dianutnya. ${ }^{5}$ Hubungan memiliki jenis yang bervariasi, yaitu hubungan dengan teman sebaya, orang tua, keluarga, dan lingkungan sosial. Secara garis besar, hubungan terbagi menjadi hubungan positif dan negatif. Hubungan positif merupakan hubungan yang memiliki keselarasan timbal baik, dimana pihak yang berinteraksi saling menguntungkan satu sama lain secara timbal balik. Sedangkan, hubungan yang negatif merupakan hubungan yang berdampak pada kerugian di mana kedua belah pihak yang berinteraksi tidak memiliki keselarasan, ada yang dirugikan dan ada yang diuntungkan. ${ }^{6}$

Setiap anak tentunya mengharapkan terjalinnya hubungan yang harmonis didalam keluarga mereka, namun pada faktanya banyak masalah yang terjadi didalam keluarga, seperti perceraian orang tua, ekonomi, dan kekerasan di dalam keluarga (Bennett, December 18, 2018). Ketika seorang anak dapat bersenang-senanag dan menghabiskan waktu dengan orang tuanya, hal ini akan berpengaruh terhadap kehidupan seorang anak tersebut, namun sebaliknya, jika didalam keluarga seorang anak kurang bahagia dan kurang bersukacita anak akan mengalami pengaruh negatif terhadap hubungan kepribadiannya, kecerdasannya, keterampilan berpikirnya, kreativitasnya, dan pencapaian akademiknya (Badri et al, 2018). ${ }^{7}$ Hubungan yang positif akan menghasilkan dampak yang positif, sedangkan hubungan yang negatif akan menghasilkan dampak yang negatif pula. Dalam suatu hubungan yang terjalin di dalam anggota keluarga, baik antara orang tua dan anak memiliki pengaruh yang besar terlebih bagi Pendidikan seorang anak itu sendiri. Orang tua merupakan faktor yang berpengaruh bagi motivasi belajar anak. Beberapa faktor dari orangtua yang berpengaruh tersebut diantaranya: orangtua sebagai penyedia sarana belajar, orangtua bertugas memberikan bantuan dan tindakan, orangtua memberikan perhatian dan kasih sayang serta pujian kepada anaknya. ${ }^{8}$

Jika dalam keluarga orang tua dan anak memiliki hubungan yang positif maka hal itu sebagai bentuk dukungan bagi anak itu sendiri, tetapi sebaliknya jika hubungan antara orang tua dan anak didalam keluarga terjalin secara negatif maka hal itu akan menjadi penghambat bagi

\footnotetext{
${ }^{5}$ Muftiah Yulismi, "Konseling Keluarga Pada Keluarga Dengan Anak Berkebutuhan Khusus," Salemba Medika 514, no. 1 (2011): 110-125. https://doi.org/10.17509/e.v1i1.12368

${ }^{6}$ Wikipedia

${ }^{7}$ Wia Wulandari, "Hubungan Keharmonisan Keluarga Terhadap Perilaku Negatif Murid Sekolah Dasar Teologi Kristen Pelangi Kristus Surabaya," Aletheia Christian Educators Journal 2, no. 2 (2021): 164-170. https://doi.org/10.9744/aletheia.2.2

${ }^{8}$ Wira Solina, Erlamsyah Erlamsyah, and Syahniar Syahniar, "Hubungan Antara Perlakuan Orangtua Dengan Motivasi Belajar Siswa Disekolah,” Konselor 2, no. 1 (2013): 289-294. https://doi.org/10.24036/02013211247-0-00
} 
seorang anak dan dapat berdampak bagi Pendidikan anak itu sendiri. Orang tua sebagai sarana untuk mendukung setiap hal yang diperlukan oleh anaknya, termasuk sebagai sarana untuk mencapai pendidikan bagi anaknya. Jika orang tua dan anak memiliki hubungan yang positif maka seorang anak akan merasa aman, nyaman, bahkan percaya bahwa orang tuanya dapat menjadi tempat untuk mencapai segala hal yang ingin dia tuju termasuk dalam pendidikannya, tetapi sebaliknya jika orang tua dan anak memiliki hubungan yang negatif maka anak akan merasa tidak nyaman bahkan pendidikannya pun dapat terbengkalai dan tidak terurus karena ia merasa orang tuanya adalah satu-satunnya sarana untuk mendukung pendidikannya, karena didalam keluarga orang tua bukan hanya berperan sebagai sarana untuk mencapai tujuan Pendidikan seorang anak melainkan juga sebagai tempat belajar bagi anak itu sendiri.

Hubungan yang negatif antara orang tua dan anak akan berpengaruh pada pola belajar dan hasil belajar pada dunia pendidikan anak tersebut. Terdapat beberapa pengaruh yang timbul dari hubungan yang negatif antara orang tua dan anak tersebut yaitu menyebabkan anak tersebut berhenti bersekolah, atau bahkan tetap bersekolah namun memiliki hasil belajar yang menurun, oleh karena itu dalam hal ini diperlukan kerjasama antara orang tua dan anak untuk menciptakan suatu hubungan yang positif, saling menguntungkan, bukan hubungan yang negatif yang berdampak buruk bagi pendidikan seorang anak bahkan dapat mengancam masa depan anak itu sendiri.

Berdasarkan uraian di atas terdapat masalah mengenai hubungan antara orangtua dan anak yang berdampak pada hasil belajar sehingga peneliti tertarik untuk melakukan penelitian dengan judul peran hubungan orang tua dengan anak dalam proses pembelajaran di masa Covid 19.

\section{METODE}

Jenis penelitian yang digunakan oleh peneliti adalah penelitian deskriptif kualitatif. Yaitu menggunakan pendekatan kualitatif dengan mendeskripsikan data yang peneliti diperoleh sebagai hasil suatu penelitian. Menurut Malhotra pendekatan kualitatif merupakan pendeskripsian masalah penelitian berdasarkan deskripsi isu atau kebutuhan mengenai penjelasan mengenai beberapa variabel. ${ }^{9}$ Teknik pengumpulan data dalam penelitian ini dengan

\footnotetext{
${ }^{9}$ Wahyu Trisnawati and Sugito Sugito, "Pendidikan Anak Dalam Keluarga Era Covid-19,” Jurnal Obsesi : Jurnal Pendidikan Anak Usia Dini 5, no. 1 (2020): 823-831. https://doi.org/10.31004/obsesi.v5i1.71.
} 
menggunakan beberapa sumber buku dan jurnal sebagai bahan pengkajian dari penelitian yang akan dibahas.

\section{HASIL}

Sejak lahir anak-anak sudah diperkenalkan dengan hubungan sosial yang terjalin didalam lingkungan keluarga, dimana anak tersebut bertumbuh dan berinteraksi dengan anggota keluarganya terlebih ayah dan ibunya. ${ }^{10}$ Dalam sebuah keluarga diperlukan adanya hubungan yang positif antara anak dan orang tua, orang tua menghargai anak dan anak menghargai orang tua. Hubungan yang positif ini dapat berupa suatu hubungan yang harmonis, yang terjalin antar anggota keluarga, terlebih antara orangtua dan anak. Menurut keberadaannya di dunia, keluarga memiliki suatu tujuan yang mulia, yaitu keluarga dapat dijadikan sebagai tempat yang aman, serta dapat menciptakan suasana cinta kasih yang saling diberikan antar anggota keluarga, baik antara suami dan istri, bahkan antara orang tua dan anak sehingga setiap anggota keluarga dapat bertumbuh dan berkembang menjadi pribadi yang dewasa. ${ }^{11}$

Anak merupakan aset berharga dan calon generasi penerus dari orang tua, oleh karena itu orang tua perlu membimbing anaknya menjadi pribadi yang baik. Orangtua bukan hanya berperan sebagai sarana pemenuhan kebutuhan hidup anaknya saja, tetapi orangtua juga bertanggung jawab dalam menentukan mada depan seorang anak. Orangtua dan keluarga berperan penting dalam memberikan dukungan dan tanggung jawab memfasilitasi anak dalam Pendidikan. ${ }^{12}$ Dalam hal ini orangtua sangat berperan penting untuk memberikan dukungan dalam mengejar masa depan anaknya, orang tua bertanggungjawab menyekolahkan anaknya dan hal tersebut dapat menjadi sarana untuk meningkatkan prestasi anaknya. Namun dalam hal ini orang tua tidak hanya sekedar menyekolahkan anaknya saja melainkan juga dapat memberikan

${ }^{10}$ Christiani Hutabarat, Sutrisno, "Orangtua Dan Teman Bermain Terhadap Perkembangan Sosial Anak," Journal of Theology and Christianity Studies 1, no. Vol 1 No 1 (2019): QUAERENS: Journal of Theology and Christianity Studies (2019). https://doi.org/10.46362/quaerens.v1i1.15.

${ }^{11}$ Handry David Rumimpinu, Marthin Steven Lumingkewas, and Sutrisno, "The Quality Of The Christian Family According To Colossians 3 : 18-21," Quaerens 2, no. 2 (2020): 147-164. https://doi.org/10.46362/quaerens.v2i2.29.

${ }^{12}$ Christiani Hutabarat, Mahayoni Mahayoni, Filyensi Misriani Laufra, and Sutrisno Sutrisno. 2021. "The Role of Parents in Building Children's Character at Home During the Covid-19 Pandemic". RERUM: Journal of Biblical Practice 1 (1):63-75. https://jurnal.moriah.ac.id/index.php/rerum/article/view/14; Christiani Hutabarat dan Bobby Kurnia Putrawan. "Pengantar Pola Asuh Orang Tua Dalam Keluarga Kristen." PNEUMATIKOS: Jurnal Teologi Kependetaan 11, no. 2 (2021): 84-94. https://stapin.ac.id/e-journal/index.php/pneumatikos/article/view/28. 
dukungan berupa kasih sayang, semangat, bahkan membantu dalam mengerjakan tugas dan tanggung jawab yang di emban oleh anaknya dalam dunia pendidikan.

Sikap perduli yang dimiliki orangtua terhadap Pendidikan anaknya merupakan salah satu bentuk hubungan yang positif antara anak dengan orang tua, yang membuat anak tersebut merasa diperhatikan dan mendapat dukungan dalam belajar dari oarngtuanya. Dalam memberikan pola asuh dan pendidikan kepada anak, orang tua dapat memulainya dengan memberikan bimbingan nasehat kepada anak, bahkan orang tua juga dapat memberikan teladan melalui sikap hidup yang ditunjukkannya dalam tahap-tahap pertumbuhan anak. ${ }^{13}$ Anak merupakan tanggungjawab dari orang tua dan anak adalah cerminan dari orangtuanya, dalam hal ini orang tua perlu memperhatikan pola asuh dan pendidikan yang diberikan kepada anaknya karena kedua hal tersebut menentukan bagaimana pertumbuhan dari seorang anak itu kedepannya. Oleh karena itu orangtua bertanggung jawab untuk memiliki sikap yang perduli terhadap anaknya, terlebih perduli akan pendidikan seorang anak yang nantinya pendidikan tersebut dapat menjadi sarana untuk mencapai masa depan, harapan, impian sang anak. Rata-rata hubungan antara orang tua dan anak memiliki pengaruh yang positif terhadap masalah belajar yang dialami anak. Hasil ini sejalan dengan penelitian Bangun (2008) yang menyataan bahwa hubungan antara anak dengan orang tua mempengaruhi prestasi seorang anak dalam dunia Pendidikan. Hubungan yang positif menunjukkan adanya kepedulian dari orang tua terhadap pendidikan anaknya, kepedulian tersebut dapat berupa: menyediakan fasilitas belajar, mengawasi kegiatan belajar anak. Memberikan penghargaan terhadap nilai yang diperoleh, serta orangtua memiliki keinginan mengenal guru yang mengajar anaknya. Sedangkan hubungan yang negatif antara orangtua dengan anaknya dapat berupa: pengucapan kata-kata negatif dari orang tua kepada anaknya, orang tua kurang memperhatikan kehidupan anaknya, maupun orangtua kurang mendukung prestasi anaknya dalam dunia pendidikan. Data ini sejalan dengan penelitian Bangun yang menyebutkan bahwa orangtua yang tidak memperhatikan dan tidak perduli pada pendidikan anaknya, megakibatkan anak anak tersebut tidak termotivasi dalam belajar dan anak menggangap bahwa orangtuanya tidak mendukung belajarnya sehingga anak merasa pembelajaran yang dia

\footnotetext{
${ }^{13}$ Sutrisno, Dkk. Penerapan Nilai Karakter Bagi Kaum Proletar Usia Remaja di Yayasan Kemah Kasih. Jurnal Pengabdian dan Pemberdayaan Masyarakat, Vol.3 No.2, Desember 2021. https://doi.org/10.24036/abdi.v3i2.123.
} 
lakukan adalah hal yang sia-sia. ${ }^{14}$ Sering kali anak yang merasa tidak memiliki dukungan dari orangtuanya dalam belajar mengalami kurang berkonsentarsi dalam melakukan pembelajaran. Anak tersebut cenderung murung, pendiam bahkan tidak fokus dalam mengerjakan segala sesuatu ketika belajar, karena anak tersebut merasa bahwa ketika dia belajar itu adalah hal yang sia-sia karena anak tersebut tidak mendapatkan dukungan dari orangtuanya.

Dalam melakukan pembelajaran di sekolah diperlukan adanya konsentarsi dan korelasi yang baik antara guru dan muridnya, guru menjalankan tugas dan tanggung jawabnya dengan baik dalam memberikan pengajaran baik peserta didiknya. Demikian juga seorang peserta didik dapat menjadi pribadi yang bertanggungjawab yaitu dengan menjadi pelajar yang baik, berkonsentrasi dan dapat mengerjakan setiap tugas dan tanggungjawab dengan baik ketika di Sekolah. Oleh karena itu hal ini menjadi perhatian khusus dan bentuk dari tanggungjawab orang tua terhadap anaknya. Orangtua perlu mengenal siapa pengajar yang mengajari anaknya di sekolah, dan hal ini dapat menjadi jembatan bagi orangtua untuk mengenai bagaimana sikap anaknya ketika di sekolah. ${ }^{15}$ Orangtua perlu mendukung setiap hal yang diperlukan anaknya dengan cara memenuhi kebutuhan belajar si anak, bahkan orang tua juga perlu memberikan semangat kepada anaknya yang berupa kasih sayang dan perhatian kepada anak, sehingga anak akan merasa nyaman dan pikiran anak tersebut tidak terganggu oleh hal-hal lain yang dapat memicu kurangnya konsentasi dalam belajar. Jika anak memiliki perstasi yang baik dalam belajar di sekolah pastinya orangtua juga akan bangga dengan hasil belajar yang dimiliki oleh anaknya, oleh karena itu orangtua menjadi faktor penentu bagaimana perkembangan sikap, bahkan intelektual yang dimiliki oleh seorang anak.

Semua keluarga pastinya mengharapkan terciptanya hubungan yang harmonis di dalam rumah tangga mereka. Dengan kehadiran seorang anak, hal tersebut menjadi suatu kebanggaan dan sumber kebahagiaan bagi orang tua. Didalam hubungannya orang tua yang merupakan pasangan suami istri harus memperhatikan hubungan keharmonisan di dalam keluarga mereka,

\footnotetext{
${ }^{14}$ K Yunanda Luxiana, A A I Agung Rai Sudiatmika, and N. L. Pande Latria Devi Devi, "Pengaruh Teman Sebaya, Orang Tua, Dan Guru Terhadap Masalah Belajar Anak Superior” 1, no. April (2018): 1-11. https://doi.org/10.23887/jppsi.v1i1.21911

${ }^{15}$ Yusak Tanasyah, Iswahyudi, dan Steven Phang. "Membangun Kepemimpinan Kristen Entrepreneurial Sebagai Landasan Keberhasilan Upaya Memimpin (Building Entrepreneurial Christian Leadership As A Fundamental Of Successful Leading Efforts)". QUAERENS: Journal of Theology and Christianity Studies 2, no.2 (2020): 127-46. https://doi.org/10.46362/quaerens.v2i2.19; Sri Wahyuni dan Yan Kristianus Kadang. "Mendidik Anak (Educating Children)". QUAERENS: Journal of Theology and Christianity Studies 1, no. 2 (December 2, 2019): 122-143. Accessed December 13, 2021. https://doi.org/10.46362/quaerens.v1i2.6.
} 
yang memiliki arti bahwa orang tua harus memiliki kesatuan dalam bersikap terhadap anak mereka. Karena dalam hal kesatuan sikap tersebut, baik pandangan maupun prinsip hidup memiliki peranan yang penting bagi perkembangan anak. ${ }^{16}$

Keberhasilan dan kesuksesan dalam mengasuh serta mendidik anak untuk menjadi manusia yang bermanfaat bagi nusa dan bangsa merupakan harapan bagi setiap orangtua. Namun seiring berjalannya waktu, tidak semua pasangan suami istri mampu memelihara keharmonisan dan mendidik anak-anaknya dengan baik (Isminayah \& Supandi, 2016; Syahrul \& Datuk, 2018). Hal ini sangat berpengaruh terhadap tingkat prestasi anak Ketika di Sekolah. ${ }^{17}$ Oleh karena itu setiap anggota keluarga perlu memperhatikan hubungan didalam keluarga mereka. Setiap orangtua mengharapkan terciptanya hubungan yang harmonis di dalam rumah tangga mereka, dengan demikian diperlukan adanya kerjasama dalam membangun hubungan yang harmonis tersebut, yaitu dengan menciptakan hubungan yang positif antar sesama anggota keluarga berupa rasa saling menghargai- menghormati, saling menyayangi, saling mendukung, bahkan saling mengasihi, sehingga hubungan yang positif tersebut dapat menciptakan keharmonisan dalam sebuag keluarga.

\section{PEMBAHASAN}

Dalam hubungan rumah tangga diperlukan adanya hubungan yang positif, yang menjadi hal utama yang harus dimiliki oleh setiap keluarga. Diharapkan dalam setiap anggota keluarga dapat memiliki hubungan yang positif dengan cara menciptakan hubungan yang harmonis. Untuk menciptakan keharmonisan dalam keluarga diprelukan adanya rasa saling menghargai, menghormati antara istri dengan suami, anak dengan orangtua, bahkan orangtua dengan anak, tidak hanya itu keluarga yang harmonis adalah keluarga yang memiliki kerukunan, kedamaian, kebahagiaan, penuh cinta dan kasih serta tidak terdapat konflik dalam keluarga serta menjalankan tugas dan tanggung jawab masing-masing berlandaskan kepada norma-norma agama yang berlaku (Aulia, 2015; Syahrul, 2020; Rahmawati, Zahrawati, Pathuddin, \& Khatimah, 2019), ${ }^{18}$ dengan demikian diharapkan dalam sebuah keluarga antara orangtua dan anak memiliki rasa saling menghargai, menghormati, menciptakan kerukunan, kedamaian, penuh

\footnotetext{
16 Christiani Hutabarat, Sutrisno, “Orangtua Dan Teman Bermain Terhadap Perkembangan Sosial Anak.”

${ }^{17}$ Irmansyarif, "Dampak Keharmonisan Keluarga Dan Pola Asuh Orangtua Terhadap Prestasi Belajar Siswa SDN 113 Pana.” https://doi.org/10.35905/almaarief.v2i1.1540

${ }^{18}$ Ibid.
} 
cinta dan kasih terlebih-lebih tidak memiliki konflik dalam keluarga, sehingga keharmonisan dalam keluarga tersebut dapat terjalin dengan baik.

Menurut Mohammad (2011), di dalam hal kehilangan emosional rasa aman dalam keluarga akan mempengaruhi psikologis anak untuk keberlangsungan kehidupannya ada beberapa kebutuhan utama anak yang penting untuk dipenuhi, yaitu: (a). Kebutuhan akan adanya kasih sayang; (b). Kebutuhan akan keikutsertaan dan diterima dalam kelompok; (c). Kebutuhan untuk berdiri sendiri; (d). Kebutuhan untuk berprestasi; (e). Kebutuhan akan pengakuan dari orang lain. ${ }^{19}$ Orang tua adalah teladan bagi anak-anaknya dalam berperilaku, (Nasution, 2019). Orang tua yang baik adalah orang tua yang berperan dengan cara melindungi anaknya dari masalah perkembangan psikologis, berupa depresi, kecemasan, perilaku anti social, bahkan mampu mengembangkan kualitas diri seorang anak yaitu dari hal kejujuran, empati, pengendalian diri, kemandirian, keceriaan, serta kebaikan. ${ }^{20}$ Dalam hal ini orangtua perlu memperhatikan setiap perlakuan sikap yang dimilikinya terhadap anaknya, orangtua yang bersikap baik kepada anaknya adalah orang tua yang baik dan bertanggungjawab, dan orang tua yang memiliki hubungan yang baik dengan anaknya serta memberikan dukungan dan perhatian kepada anaknya akan berpengaruh bagi prestasi belajar yang ditampilkan anak tersebut dalam dunia pendidikan.

Untuk dapat melihat hubungan yang harmonis dalam suatu keluarga dapat dilihat dari hubungan positif yang terjalin antar anggota keluarga tersebut. Hubungan positif antara anak dengan orang tua dalam suatu keluarga dapat berupa: keterlibatan orangtua dalam menyediakan fasilitas belajar anak, orangtua mengawasi kegiatan belajar anak, orangtua menanyakan kegiatan dan hasil belajar anaknya, orangtua memberikan penghargaan terhadap prestasi belajar anak orangtua mengawasi penggunaan waktu belajar anak, serta orangtua berkeinginan untuk bisa lebih dekat dan mengenal wali kelas atau para guru yang mengajar anaknya (Bangun, 2008). Sedangkan hubungan yang negatif antara anak dengan orang tua dalam suatu keluarga dapat berupa:pengucapan kata-kata negatif, orang tua kurang memberikan perhatian dan dukungan terhadap prestasi anak yang berdampak pada kurangnya motivasi anak dalam belajar. Anak yang kurang mendapat dukungan dari orangtua akan memiliki konsep kepercayaan diri yang rendah

\footnotetext{
${ }^{19}$ Junierissa Marpaung and Kiki Dian Novitasari, "Studi Deskriptif Dampak Orang Tua Yang Berkonflik Bagi Anak," Jurnal Bimbingan dan Konseling 3, no. 2 (2017): 44-51. https://doi.org/10.33373/chypend.v3i1.869

${ }^{20}$ Sutrisno Sutrisno, Peni Hestiningrum, Marthin Steven Lumingkewas, dan Bobby Kurnia Putrawan. "Christian Religious Education Toward The Teenagers Character Building." Evangelikal: Jurnal Teologi Injili dan Pembinaan Warga Jemaat Vol.5, No.2 (2021): 202-212. https:doi.org/10.46445/ejti.v5i2.330.
} 
karena anak merasa bahwa pembelajaran yang dilakukan olehnya adalah hal yang sia-sia. Bangun (2008) yang menyebutkan bahwa orang tua yang tidak memperhatikan pendidikan anaknya atau tidak peduli dengan kegiatan belajar anaknya, akan mengakibatkan anak tidak termotivasi dalam belajar. ${ }^{21}$ Oleh karena itu dalam hal ini anggota keluarga terlebih orangtua dapat memperhatikan hubungan yang terjalain di dalam anggota keluarganya, karen suatu hubungan tersebut memiliki pengaruh yang besar dan menjadi arah penentu bagaimana kehidupan keluarga tersebut akan berlangsung. Ketersediaan adanya sebuah keluarga merupakan anugerah yang luar biasa dan memerlukan tanggungjawab yang besar untuk mengelolanya, oleh karena itu orangtua perlu persiapan yang matang dan mempersiapkan dari jauh hari bagaimana hubungan dalam keluarga mereka dan bagaimana arah keluarga mereka akan berjalan.

Keluarga yang memiliki hubungan yang negatif yaitu antara anak dan orang tua akan mengakibatkan dampak yang negatif pula, terlebih bagi psikologi anak itu sendiri. Anak yang sudah terbiasa dengan pola hubungan yang negatif akan merasa acuh tak acuh akan dirinya sendiri bahkan keluarganya, anak tersebut akan memiliki rasa ketidakperdulian terhadap dirinya dan lingkungan sekitarnya, karena ia merasa tidak ada hal lain yang dapat diperoleh karena tidak ada oknum yang mendukungnya dan dapat memperhatikan kehidupannya. Anak yang memiliki hubungan yang negatif dengan orangtuanya akan mempengaruhi proses belajar dan prestasinya di sekolah. Hasil penelitian Andi Ilham Muchtar (2009) mengungkapkan bahwa keluarga yang memiliki kurangnya keharmonisan menjadi faktor penyebab terjadinya penurunan prestasi belajar seorang anak. ${ }^{22}$ Oleh karena itu hubungan memiliki pengaruh yang besar dan berdampak bagi hasil belajar seorang anak, jika orangtua lalai dalam memperhatikan hubungan dengan anaknya maka hal tersebut akan mengakibatkan pengaruh yang besar bagi pendidikan seorang anak.

Pada dasarnya keluarga memiliki suatu fungsi yang penting dalam rumah tangga. Beberapa fungsi didalam keluarga tersebut, diantaranya:

a. Fungsi Ekonomis

\footnotetext{
${ }^{21}$ Luxiana, Sudiatmika, and Devi, "Pengaruh Teman Sebaya, Orang Tua, Dan Guru Terhadap Masalah Belajar Anak Superior."

${ }^{22}$ Marpaung and Novitasari, "Studi Deskriptif Dampak Orang Tua Yang Berkonflik Bagi Anak."
} 
Didalam menjalankan fungsi ekonomis, keluarga harus menjadi suatu kesatuan yang mandiri, keluarga menjadi tempat anggota-anggota keluarganya untuk mengkonsumsi barang-barang yang telah diproduksi.

b. Fungsi Sosial

Didalam menjalankan fungsi sosial, keluarga harus mempunyai suatu prestasi atau kemampuan dan dapat memberikan status terhadap anggota-anggota keluarganya.

c. Fungsi Edukatif

Didalam menjalankan fungsi edukatif, keluarga menjadi tempat untuk memperoleh pendidikan, dengan cara memberikan atau menyalurkan pendidikan bagi anggotaanggota keluarganya.

\section{d. Fungsi Protektif}

Dalam menjalankan fungsi protektif, keluarga dapat memberikan perlindungan bagi anggota-anggota keluarganya, perlindungan yang diberikan tersebut baik dari ancaman fisik, ekonomis, dan psikososial.

e. Fungsi Religius

Didalam menjalankan fungsi religius, keluarga dapat mengajarkan tentang agama bagi anggota-anggota keluarganya.

\section{f. Fungsi Rekreatif}

Didalam menjalankan fungsi rekreatif, keluarga dapat menjadi pusat hiburan, tempat bersenang-senang, penyegaran kembali badan dan pikiran, bagi anggota-anggota keluarganya.

\section{g. Fungsi Afektif}

Dalam menjalankan fungsi afektif, keluarga dapat memberikan kasih sayang kepada anggota-anggota keluarganya sehingga dapat mempengaruhi mempengaruhi keadaan perasaan dan emosi. ${ }^{23}$

Dari beberapa bagian poin penting tentang fungsi keluarga diatas, diharapkan setiap anggota keluarga dapat menjalankan fungsi dari keluarga tersebut dengan baik. Keluarga yang baik adalah keluarga yang bertanggungjawab dan mampu menjalankan fungsinya sebagai

\footnotetext{
${ }^{23} \mathrm{Hj}$. Eny Suhaeni, "Fungsi Keluarga, Masyarakat Dan Pemerintah Dalam Proses Pendidikan (Tinjauan Sosiologis)" Vol 11, no. Vol 11 No 1 (2017): Januari-Juni (2020): 14-31. https://doi.org/10.33592/islamika.v11i1.416
} 
keluarga sebagaimana mestinya. Keluarga yang baik bukan hanya sekedar keluarga yang dapat menjalankan fungsinya, melainkan juga dapat memperhatikan hubungan keharmonisan dalam keluarganya yang menjadi bagian dalam penentu arah kehidupan sebuah keluarga. Jika fungdi keluarga tidak bergerak, maka akan menimbulkan suatau masalah yang besar didalam sebuah keluarga, fungsi keluarga tersebut menentukan keharmonisan didalam sebuah keluarga.

\section{KESIMPULAN}

Keluarga adalah anggota yang terdiri atas dua orang atau lebih yang disatukan oleh ikatan-ikatan kebersamaan, emosi, dan yang mengidentifikasi diri mereka sebagai anggota keluarga. Keluarga mengambil peranan penting dalam mendidik anak-anak mereka. Keluarga berfungsi untuk memberikan kontribusi bagi kemajuan pendidikan. Anak merupakan aset berharga dan calon generasi penerus dari orang tua. Hubungan terjadi dalam setiap proses kehidupan manusia. Suatu hubungan dapat ditemukan baik dilingkungan sekolah, masyarakat bahkan di dalam keluarga. Hubungan di dalam anggota keluarga sangat memiliki pengaruh besar terhadap pendidikan anak. Secara garis besar, hubungan terbagi menjadi hubungan positif dan negatif. Anak yang memiliki hubungan yang negatif dengan orangtuanya akan mempengaruhi proses belajar dan prestasinya di sekolah. Dalam sebuah keluarga diperlukan adanya hubungan yang positif antara anak dan orang tua, dan keluarga diharapkan dapat menjalankan fungsinya sebagaimana mestinya sehingga terjalin suatu hubungan yang baik antar anggota keluarga.

\section{KEPUSTAKAAN}

Agustin, Reni, and Widayatmoko Widayatmoko. "Pengaruh Komunikasi Interpersonal Dan Iklim Komunikasi Organisasi Terhadap Kepuasan Komunikasi Karyawan Sekretariat Jenderal Kementerian Komunikasi Dan Informatika.” Koneksi 3, no. 1 (2019): 163. https://doi.org/10.24912/kn.v3i1.6198

Dubey, Divya. "Psychological Impact Of Covid-19." COVID-19 Pandemic Update 2020. Royal Book Publishing, 2020. https://doi.org/10.26524/royal.37.15

Hantono, Dedi, and Diananta Pramitasari. “Aspek Perilaku Manusia Sebagai Makhluk Individu Dan Sosial Pada Ruang Terbuka Publik.” Nature: National Academic Journal of Architecture 5, no. 2 (2018): 85. https://doi.org/10.24252/nature.v5i2a1.

Hutabarat, Christiani, and Bobby Kurnia Putrawan. "Pengantar Pola Asuh Orang Tua Dalam 
Keluarga Kristen." PNEUMATIKOS: Jurnal Teologi Kependetaan 11, no. 2 (2021): 8494. https://stapin.ac.id/e-journal/index.php/pneumatikos/article/view/28.

Luxiana, K Yunanda, A A I Agung Rai Sudiatmika, and N. L. Pande Latria Devi Devi. "Pengaruh Teman Sebaya, Orang Tua, Dan Guru Terhadap Masalah Belajar Anak Superior" 1, no. April (2018): 1-11. https://doi.org/10.23887/jppsi.v1i1.21911

Marpaung, Junierissa, and Kiki Dian Novitasari. "Studi Deskriptif Dampak Orang Tua Yang Berkonflik Bagi Anak.” Jurnal Bimbingan dan Konseling 3, no. 2 (2017): 44-51. https://doi.org/10.33373/chypend.v3i1.869

Rumimpinu, Handry David, Marthin Steven Lumingkewas, and Sutrisno. "The Quality Of The Christian Family According To Colossians 3 : 18-21." Quaerens 2, no. 2 (2020): 147164. https://doi.org/10.46362/quaerens.v2i2.29

Solina, Wira, Erlamsyah Erlamsyah, and Syahniar Syahniar. "Hubungan Antara Perlakuan Orangtua Dengan Motivasi Belajar Siswa Disekolah.” Konselor 2, no. 1 (2013): 289294. https://doi.org/10.24036/02013211247-0-00

Suhaeni, Hj. Eny. "Fungsi Keluarga, Masyarakat Dan Pemerintah Dalam Proses Pendidikan (Tinjauan Sosiologis)" Vol 11, no. Vol 11 No 1 (2017): Januari-Juni (2020): 14-31. https://doi.org/10.33592/islamika.v11i1.416

Sutrisno, Dkk. Penerapan Nilai Karakter Bagi Kaum Proletar Usia Remaja di Yayasan Kemah Kasih. Jurnal Pengabdian dan Pemberdayaan Masyarakat ISSN: 2656-369X (Print), 2684-8570 (Online) Vol.3, No.2, Desember 2021 http://abdi.ppj.unp.ac.id/index.php/abdi Email:abdi@ppj.unp.ac.id DOI:https://doi.org/10.24036/abdi.v3i2.123.

Sutrisno, Peni Hestiningrum, Marthin Steven Lumingkewas, dan Bobby Kurnia Putrawan. "Christian Religious Education Toward The Teenagers Character Building." Evangelikal: Jurnal Teologi Injili dan Pembinaan Warga Jemaat Vol.5, No.2 (2021): 202-212. https:doi.org/10.46445/ejti.v5i2.330.

Hutabarat, Christiani Sutrisno. "Orangtua Dan Teman Bermain Terhadap Perkembangan Sosial Anak." Journal of Theology and Christianity Studies 1, Vol.1, No.1 (2019): https://doi.org/10.46362/quaerens.v1i1.15

Hutabarat, Christiani, Mahayoni Mahayoni, Filyensi Misriani Laufra, and Sutrisno Sutrisno. 2021. “The Role of Parents in Building Children's Character at Home During the 
Covid-19 Pandemic". RERUM: Journal of Biblical Practice 1 (1):63-75. https://jurnal.moriah.ac.id/index.php/rerum/article/view/14.

Tanasyah, Y., Iswahyudi, dan Steven Phang. "Membangun Kepemimpinan Kristen Entrepreneurial Sebagai Landasan Keberhasilan Upaya Memimpin (Building Entrepreneurial Christian Leadership As A Fundamental Of Successful Leading Efforts)". QUAERENS: Journal of Theology and Christianity Studies 2, no.2 (2020): 127-46. https://doi.org/10.46362/quaerens.v2i2.19.

Trisnawati, Wahyu, and Sugito Sugito. "Pendidikan Anak Dalam Keluarga Era Covid-19." Jurnal Obsesi : Jurnal Pendidikan Anak Usia Dini 5, no. 1 (2020): 823-831. https://doi.org/10.31004/obsesi.v5i1.710.

Wahyuni, Sri dan Yan Kristianus Kadang. "Mendidik Anak (Educating Children)". QUAERENS: Journal of Theology and Christianity Studies 1, no. 2 (December 2, 2019): 122-143. Accessed December 13, 2021. https://doi.org/10.46362/quaerens.v1i2.6.

Wulandari, Wia. "Hubungan Keharmonisan Keluarga Terhadap Perilaku Negatif Murid Sekolah Dasar Teologi Kristen Pelangi Kristus Surabaya.” Aletheia Christian Educators Journal 2, no. 2 (2021): 164-170. https://doi.org/10.9744/aletheia.2.2.164-170.

Yulismi, Muftiah. "Konseling Keluarga Pada Keluarga Dengan Anak Berkebutuhan Khusus." Salemba Medika 514, no. 1 (2011): 110-125. https://doi.org/10.17509/e.v1i1.12368. 